\title{
視覚が水平振動感覚に及ぼす影響に関する研究 INFLUENCE OF VISUAL SENSATION ON SENSE OF HORIZONTAL VIBRATION
}

\author{
野田 千津子**, 石川孝重* \\ Chizuko NODA and Takashige ISHIKAWA
}

\begin{abstract}
Experiments have been carried out to determine the sense of horizontal vibration where subjects can see the view from a window. A gap between physical feeling and visual amplitude of vibration can cause discomfort and an uneasy feeling in the high frequency and acceleration range. The visual situation has the greatest influence on vibration perception, and this is closely connected with vibration amplitude. Vibrations can not be perceived physically in the low frequency and small acceleration range, but they can be recognized visually as movement of the view. Therefore, many subjects can perceive vibrations when they can see the view. It is therefore necessary to assess the perception threshold in consideration of the influence of visual sensation. The visual sensation does not influence perception in the high frequency range, because the vibration amplitude is imperceptible in that range. It is therefore possible to assess vibrations on the basis of perception threshold scatter by physical feeling in the body.
\end{abstract}

Keywords: Horizontal vibration, Sense of vibration, Visual sensation, Perception threshold, Psychological evaluation, Habitability 水平振動, 振動感覚, 視覚, 知覚䦭, 心理評価, 居住性能

\section{1. はじめに}

本学会の居住性能評価指針" も含め, 既往の振動に関する評価規 準類は体感による知覚閾を基盤としている。しかし実存の超高層住 宅や免震建物におけるアンケート調査 ${ }^{2 \cdot 3 !}$ からもわかるように，実 際には居住者は家具や空の外の景色の動きを見たり，風や建物のき しみ音を聞いたりすることで摇れていることに気がつく場合がある。

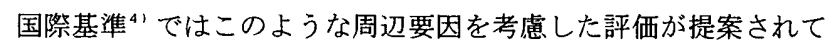
いるが，その影響を定量的に把握したものではなく，具体的な評価 值になっていないのが現状である。周辺要因の影響を加味して，実 状により近い状況における居住性能評価とするためには, 視覚や聴 覚などの周辺要因が水平振動感覚に及ぼす影響を明らかにすること が必要になる。

そこで本研究では，周辺要因の中で視覚が水平振動感覚に及ぼす 影響に着目した。実際の居住環境において，振動を感じる視覚的な きっかけを与えるものには, 室内の照明器具や什器類, 水面や空の 外の景色などがある。 ${ }^{2,31}$ 本論文では，空外の景色が見える状態で 水平振動を受ける被験者の感覚を知る実験を行った。

筆者らはこれまでにも縦縞 ${ }^{51}$ や高層住宅の模型 ${ }^{61}$ を視対象とした 実験を行ってきたが，視対象のリアリティーに追求の余地が残って いた。そこで本論文では，空を通して屋外に広がる実際の景色が見 えるようにし，視対象を実状により近いものとした。空外の景色が
見える場合の結果と空外の景色が見えない場合”との比較から, 視 覚が水平振動の知覚䦨と心理評価に及ぼす影響を知ることが目的で ある。なお，本研究の一部は文献 ${ }^{8)}$ で速報している。

\section{2. 実験の概要}

実験では振動台上に $3 \mathrm{~m}$ 四方, 高さ $3 \mathrm{~m}$ の居室を設置した。居室 には住宅用のサッシ空や壁材，建具などを用いて生活空間に近い内 装を施してある。視覚以外の周辺要因をできるかぎり少なくするた め, 音環境にも配慮した。動電型の加振装置を用いた振動台は, 振 動発生器からの機械騒音がきわめて小さい。居室の壁には約 $10 \mathrm{~cm} の$ 吸音材を充填して外部からの騒音を $15 \mathrm{~dB}$ 程度低減できるようにした。 さらに，実験中には一定の音量で音楽を流している。

空外の景色が見えるようにして行った実験(1)における居室内部お よび外部の状況を图 1 に示す。被験者 3 名は居室壁面の高さ約 $100 \mathrm{~cm}$ にある約 $140 \times 100 \mathrm{~cm}$ の空の方を見て椅子に腰掛ける。居室の外には 約9. 3離れて平屋建物があり, 被験者は空を通してこの建物と周囲 の景色を見ることができる。椅子の位置によって若干異なるが，中 央の椅子から見た空外の景色を写真 1 に示す。左右方向の水平振動 を受けた被験者からは，この景色が相対的に左右に動いて見える。 以降の結果はこのような条件において，視覚が水平振動感覚に及ぼ す影響を知るものである。

\footnotetext{
* 日本女子大学住居学科 教授・工博

** 日本女子大学住居学科 助手・修士(家政学)
} 


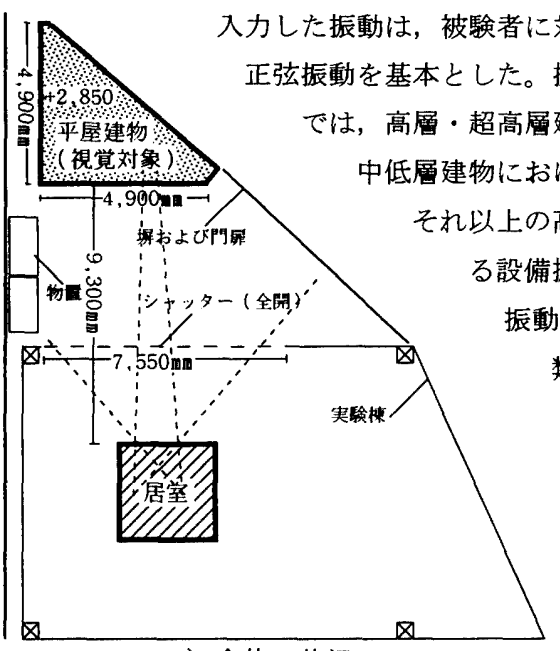

a ) 全体の状況

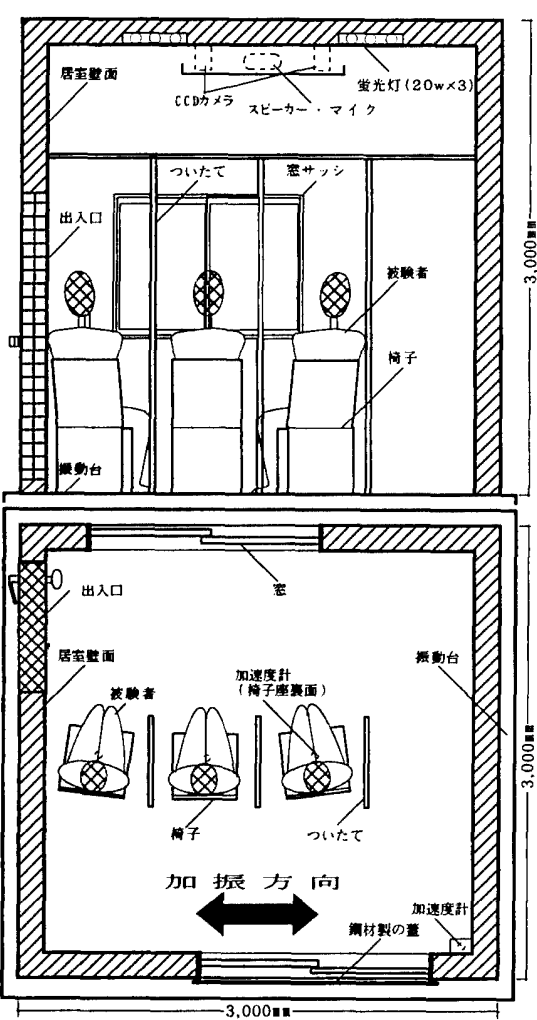

b ) 居室内部の状況

图 1 实験の状況

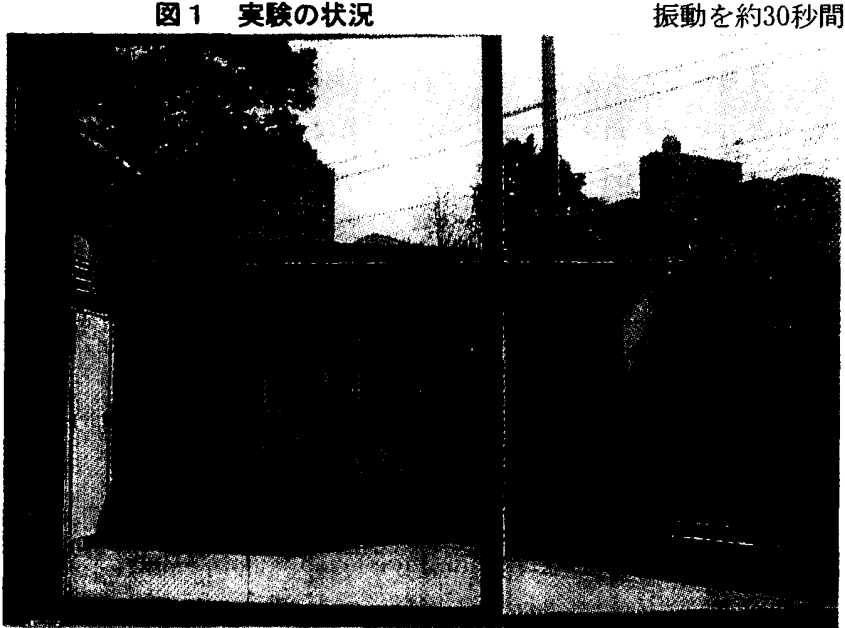

写真 1 空外の最色の状況

で示した49種

類の振動を対象

とした。この中

$1.6 \mathrm{~cm}$ の振動を

アンケートの基

準となる振動と

した。

実験中には振

動台上における

加速度をひずみ

ゲージ式加速度

計とオシログラ

フィックレコー

ダで実測し，入

力振動の再現性

をその都度確認

した。実験では 始めにアンケー トの基準となる 振動を約 30 秒間

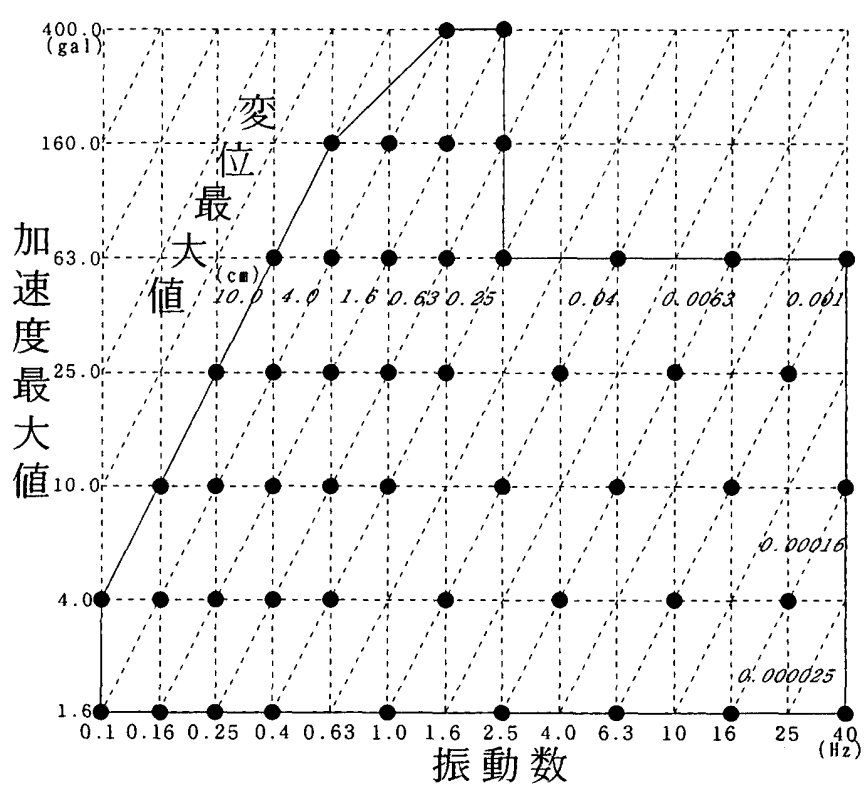

图2入力振功の目标值

で0. $63 \mathrm{~Hz}, 25 \mathrm{gal}$,

入力する。その間は空に外からスチレンボード製の覆いをし, 被験者 から空の外を見通せないようにする。すなわち,被験者はこの基準とな る振動を体感だけで感じる。その後約10秒間振動を停止している間に 実験者は空の覆いをはずし, $0.1 〜 40 \mathrm{~Hz}$ の14種類の中の任意の振動数で 加速度が徐々に大きくなる振動を入力する。被呀者は空外の累色を見 ながら振動を感じた時点で実験者に合図する。実験者はCCDカメラで 居室内の状況を外部から常にモニタリングし, 被験者の合図前後の振 動を收録する。その他，実験開始などの指示もマイクで外から行った。 一方，任意の振動数で加速度を徐々に大きくしている間，图2に ○で示した所定の加速度で振動を定常にし，実験者はアンケートに 回答するように指示する。被験者は振動を感じるか否かにかかわら ず，指示がある度に图 3 に示したアンケートに回答する。各設問の 詳細は結果に関する次章で述べる。

\begin{tabular}{|c|c|c|c|}
\hline Q1 & 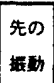 & 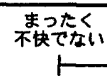 & 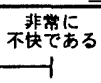 \\
\hline
\end{tabular}
フンクートの

\begin{tabular}{|c|c|c|c|c|c|c|}
\hline Q 1 & \multirow{2}{*}{$\begin{array}{l}\text { a } \\
\text { の }\end{array}$} & \multicolumn{5}{|c|}{ 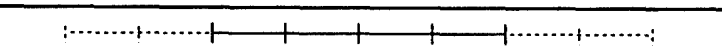 } \\
\hline & & 大表さ贯合 & 1 & 1 & & \\
\hline & 振 & 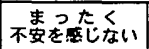 & 不要を唯しない & 不安を洁しる & 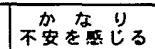 & 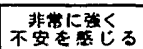 \\
\hline & 功 & & オまりりしない & 业 & <菇しる & 和えられない \\
\hline
\end{tabular}

图 3 アンケート用紙 (一部)

各振動数を入力する順序はランダムであり，1 種類の振動数の実 験が終了するごとにアンケート用紙を回収した。全被験者は女性 45 名（19歳〜24歳）である。

比較対照する空外の景色が見えない実験(2) では，居室の空を鋼 材製の蓋でふさぎ，被験者はすべての振動を体感だけで感じる。空 外の景色が見える実験(1)と異なり, 被験者は 1 名ずつ居室の床に座 っているが, 振動の入力方法やアンケート方法など，他の条件は窓 外の景色が見える実験(1)と同じである。アンケート方法の違いと比 較して, 被験者の姿勢や 1 回の実施人数が結果に及ぼす影響は小さ 
いフことを確認しているため，これまでに行った春験の中から，こ の実験(2)の結果を比較対照としてとりあげる。全被験者は女性35名 (20〜24歳) である。

\section{3. 視党が心理評価に及ぼす影罾}

图3に示したアンケートの結果から，視覚が心理評価に及ぼす影 響を知る。空外の景色が見える場合には，16Hz以上の範囲で生じる 椅子の共振による影響を考慮して，被験者ごとに実測した椅子座面 の加速度を用いて評価した。

图 4 は各振動に対する大きさ度合（アンケート用紙Q 2）の平均 值を直線補間した等評価曲線である。大きさ度合では，基準の振動 の大きさを 100 として, 各振動を感じた大きさを比較し数值で表現 する。等評価曲線は常用対数で等間隔に算出した。大きさ度合 100 の曲線上の振動は，標準振動と同じ大きさとみなされたことになる。

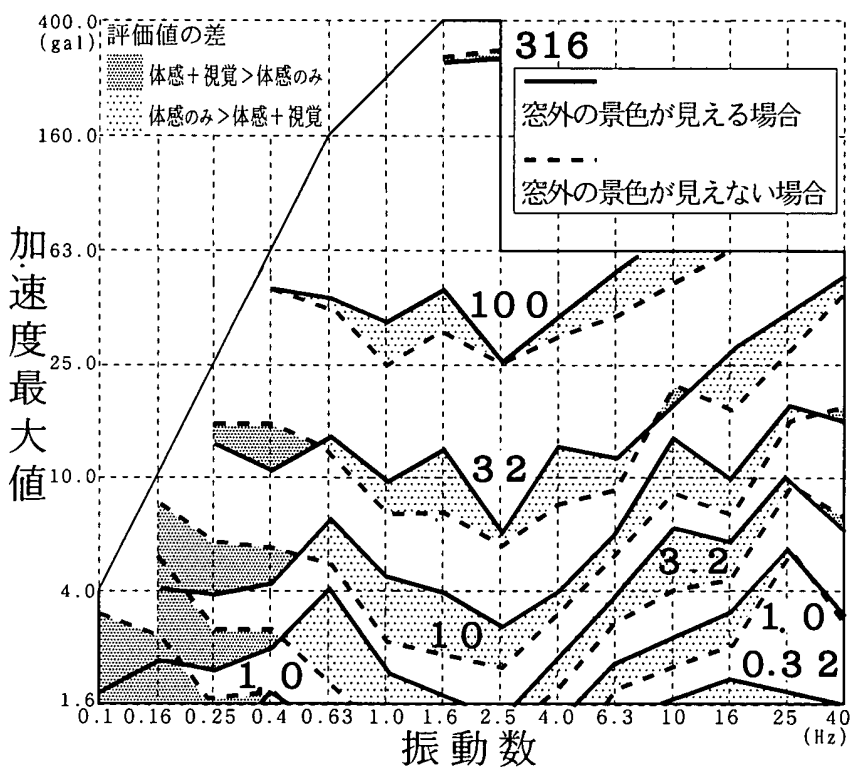

图 4 視営条件が異なる場合の大きさ度合

$25 \mathrm{gal} ， 0.4 \mathrm{~Hz}$ 以下の低振動数・低加速度範井で視覚条件による違 いが大きく，空外の景色が見える場合の方が振動を大きく感じる。 この範囲では加速度が小さくても変位が大きいため, 体感では振動 を小さいと感じるが，空外の景色が大きく動くのを見ることで，振 動をより大きく評価することがわかる。

この傾向は低振動数・低加速度籁囲に限ってみられる。その他の 範囲ではほぼ全体的に，空外の景色が見える場合の方が小さく感じ る。体感で感じる大きさと比較して空外の景色の動きは小さく見え るため，振動をより小さく評価するものと推察できる。

空外の景色の影響によって体感だけより大きく感じる範囲とより 小さく感じる範囲の境目は約0.63〜1.6cmにあたり，視覚から認識 できる振動の情報である変位の影響がみられる。

图 5 は不快度合（アンケート用紙Q 1）の等評価曲線である。不 快度合では，基準の振動に対する不快感を初めに回答し，それと比 較して各振動を感じた際の不快感を 5 段階の数直線で表す。解析で は 1 段階ごとに評価值をあてはめ，各振動と基準の振動との差をと った相対的な評価值とした。すなわち0は基準の振動と同じ不快度

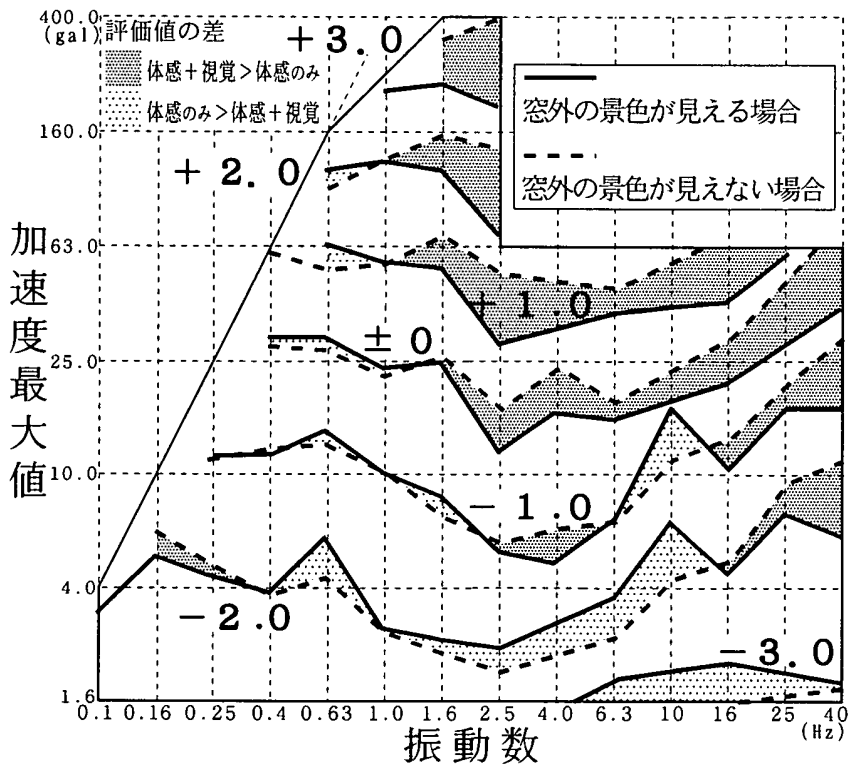

图 5 視党条件が異なる堨合の不快度合

合，プラスはより大きく，マイナスはより小さい不快度合を表す。

大きさ度合と同じように，低振動数・低加速度範囲では，空外の 景色が見える場合の方が不快感が大きい。やはり0.63〜1.6cm程度 を境に評価は逆転し，変位が小さい範囲では空外の景色が見える場 合の方が不快感が若干小さいことから，視覚の影響は変位とのかか わりが強いことがわかる。空外の景色が見える場合の方が，不快感 の小さい範囲では，大きさ度合と比較すると両者の違いは小さい。 視覚から認識できる振動の変位が小さいことは大きさの評価に強く かかわる一方，不快感に及ぼす影響は小さいことがわかる。

また1. $0 \sim 1.6 \mathrm{~Hz}$ 以上の高振動数範囲では，全体的に空外の景色が 見える場合の方が不快度合が大きい。体感ではっきりと感じる振動 でも，目に見える変位が非常に小さいために，体感と視覚による感 覚にギャップが生じ, 空外の景色が見える場合に不快感をより強く する一因となっている。実験終了後の被験者のコメントなどからも このことが確認できる。この傾向は大きさ度合にはみられず，心理 的要素の強い評価に視覚が及ぼす特徵的な影響である。

このような視覚の影響は图 6 に示した不安感（アンケート用紙 $Q$ 3），图７に示した限界評価（同Q４）にもみることができる。不 安感では各振動に対する不安感について, 限界評価は各振動を感じ た程度について，あてはまるカテゴリーを1つ選択する。それぞれ 図に示したカテゴリーについて，各振動に対する回答率を直線補間 した回答率曲線を示した。

25gal程度より加速度が大きい範囲にみられる「かなり不安を感 じる」以上と「強く感じる」以上の回答率曲線では $1.6 \mathrm{~Hz}$ を境に評 価が逆転し，高振動数範囲では空外の景色が見える場合の方が評価 の厳しい人が多い。これらも心理的要素の強い評価であり，不快度 合と共通した特徵がみられる。

一方低加速度・低振動数範囲では，共通して空外の景色が見える 場合の方が評価の厳しい人が多い。低振動数範囲では「体では感じ ない振動でも，空の外を見ると横に非常に大きく動いているのがわ かって不安だった」という被験者のコメントからも，視覚の影響に よって評価が㛜しくなっていることがわかる。また空外の景色が見 


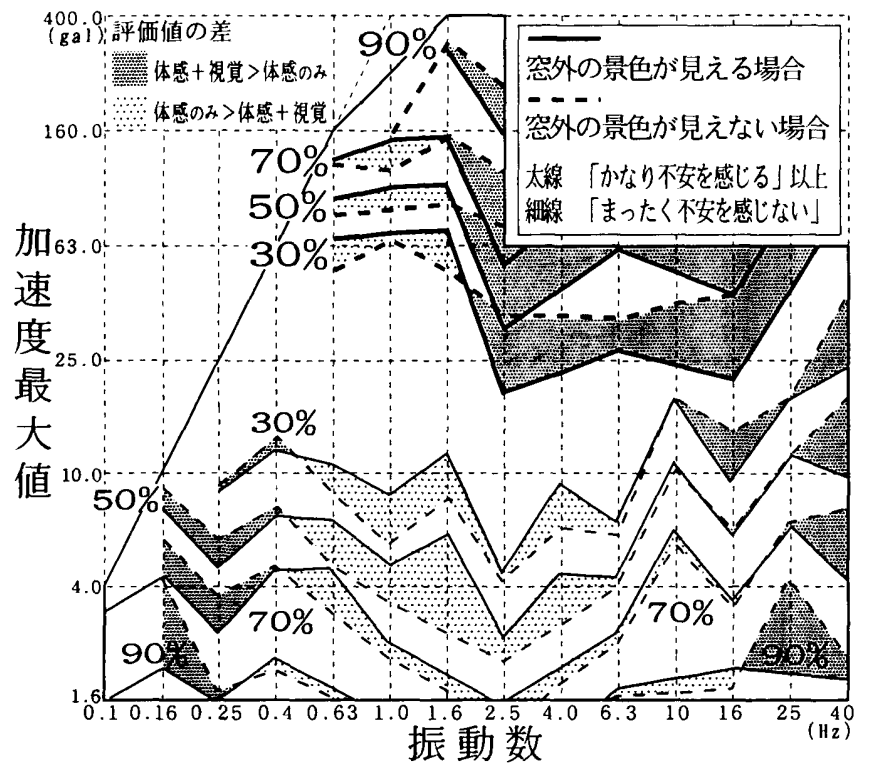

图 6 視堂策件が買なる满合の不安惑

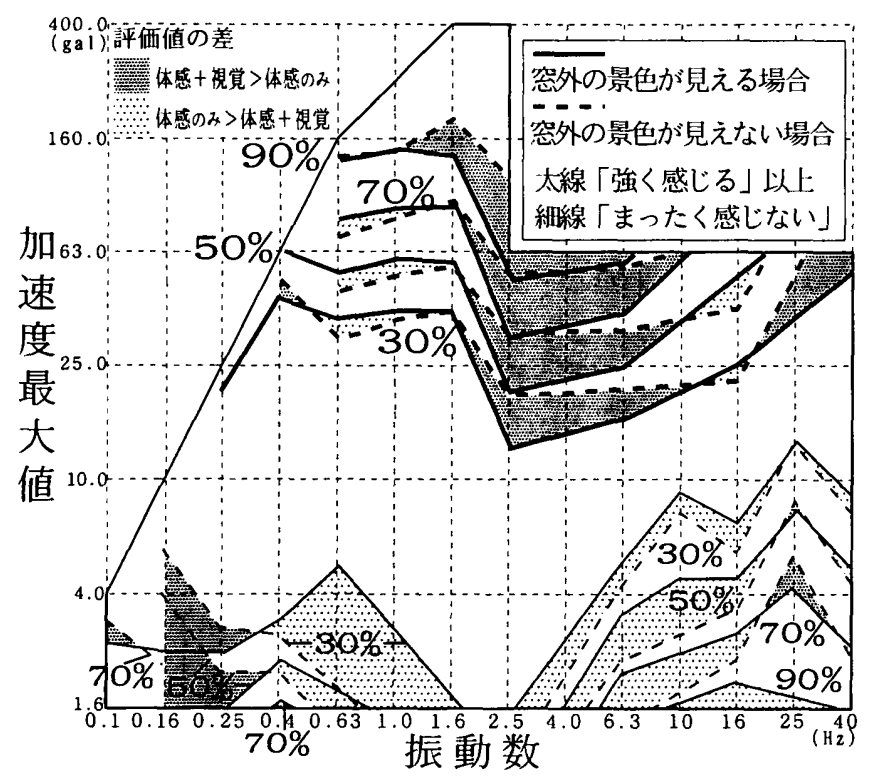

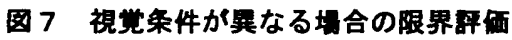

えない場合の方が評価が綮しくなる篹囲との境目は共通して0.63〜 $1.6 \mathrm{~cm}$ 付近にある。加速度が小さくても变位が大きい低振動数籍囲 におけるこのような視覚の影響は，大きさ度合と「まったく感じな い」の回答において影著にみられ，視覚条件による評価の違いも大 きい。これらは振動の物理的な大きさや知覚閥にかかわる評価であ る。すなわち，視覚がこれらの評価に大きな影響を及ぼす筑囲があ り，その影響は視覚から認識できる振動の情報である変位と関連し ていることがわかる。

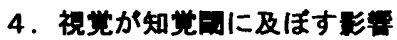

以上から，視党が知覚閾に及ぼす影響は大きいことが推察できる。 ここでは被験者が摇れを感じた合図により知覚䦥を評価し，視覚が 知觉閾に及ほす影響について述べる。解析にあたっては，空外の景 色が見える実験(1)では椅子座面の加速度，空外の景色が見えない実
験(2)では床面の加速度を用いて評価した。

图8は空外の景色が見える場合における被験者個々の知觉閶の分

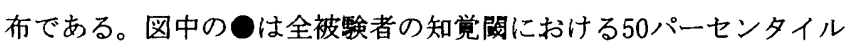
値を示す。图 9 に示した空外の景色が見えない場合には，0.16Hz以 下の籁囲で実験の最大加速度でも摇れを感じなかった被験者が多く いる。一方空外の景色が見える場合には，全振動数でほぼ全員の被 験者が摇れを感じており，低振動数篹囲における違いが大きい。

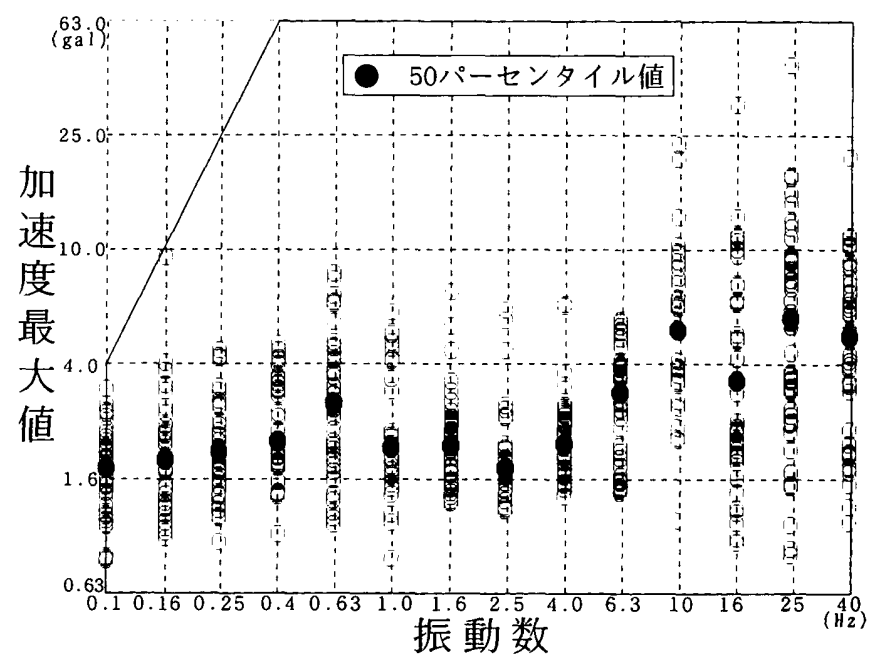

图 8 空外の量色が見える堤合の知党国の分布

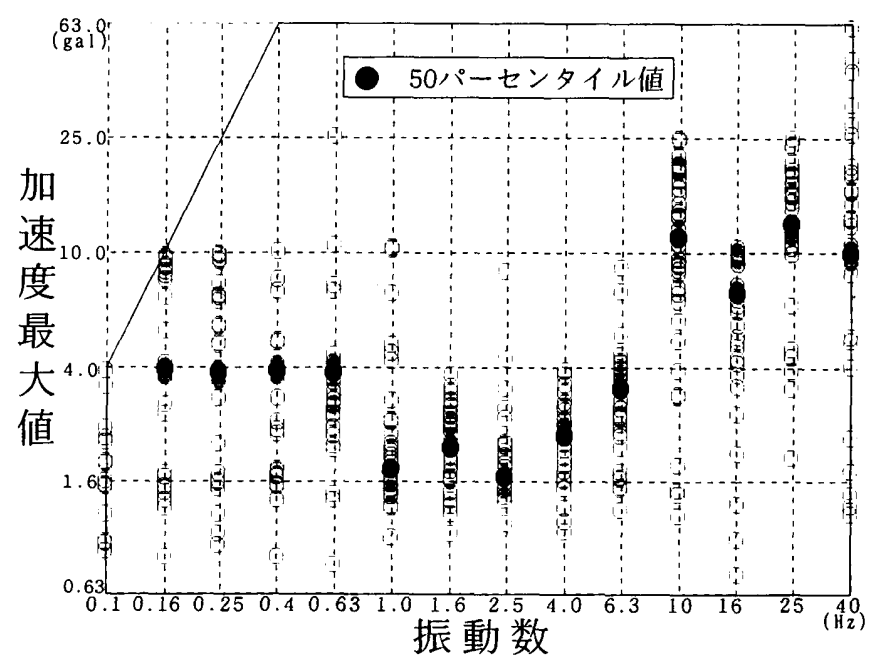

图 9 密外の最色が見えない埧合の知觉网の分布

空外の景色が見えない場合には振動数によって知喾闔のばらつき が異なるが，空外の景色が見える場合には6.3Hz程度までのばらつ きはほぼ一定である。また空外の景色が見える場合の方がばらつき は全体的に小さく, 変位が大きくなる低振動数箅囲ほど知觉䦥のぼ らつきが若干小さくなる傾向にある。空外の景色が見える場合には， 変位という視覚から明確に認識できる振動の情報を得ることによっ て, 知觉闌の個人差が小さくなるものと推察できる。変位の小さい 高振動数籁囲では視觉から振動を認識しづらいため, 空外の景色が 見えない場合の知觉闌と同じようにばらつきが大きくなる。

視覚が知觉閾に及ぼす影響を明らかにするため，両方の条件にお ける知觉閵の50パーセンタイル値を重ね合わせたものが图10である。 


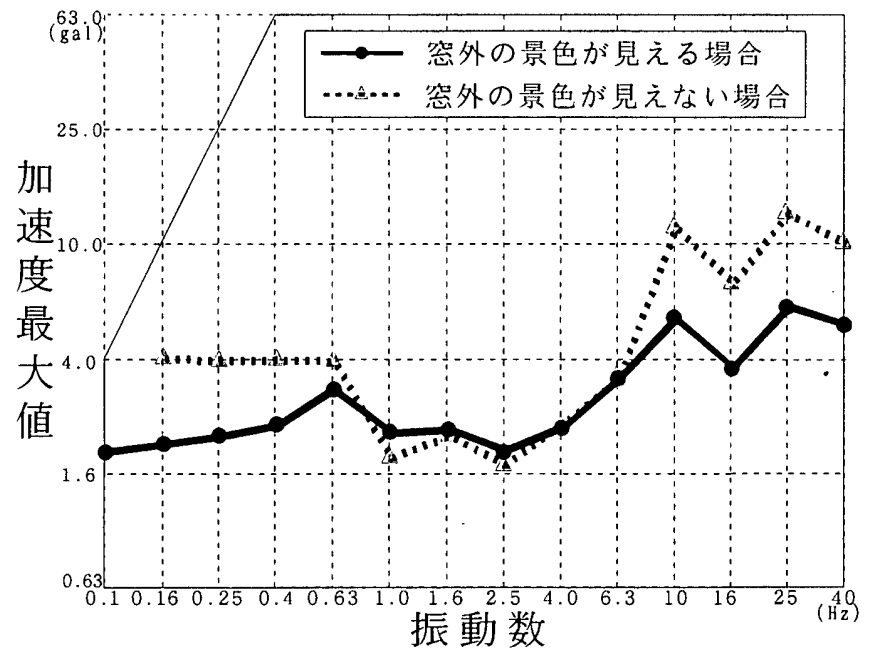

图10視觉条件が異なる場合の知觉阙

視覚条件による知覚閵の違いは $0.4 \mathrm{~Hz}$ 以下の低振動数範囲でみら れる。空外の景色が見える場合には振動数が低いほど知覚闆が小さ くなる傾向にあり，空外の景色が見えない場合との違いは低振動数 ほど大きくなる。低振動数になるほど体感で振動を感じにくくなる 一方, 視覚から認識できる変位は大きくなるため, 視覚が知賞闘に 及ぼす影響は低振動数範囲ほど大きくなるものと推察できる。すな わち体感で振動を感じない場合にも，空外の景色の動きを見ること で視覚から振動を感じていることがわかる。

$0.63 \mathrm{~Hz}$ 以上の高振動数範囲では，視覚条件によらず知覚間はほぼ 等しい。振動数が高くなるほど変位は小さくなり，空外の景色が見 える場合にも視覚から振動の変位を確認することが難しくなる。そ のため視覚の影響がほとんどなく, 知覚闘は体感に依存することが わかる。高振動数範囲で両者の知覚闘が異なる場合があるが, これ には16Hz程度から生じる椅子の共振の影響が考えられる。空外の景 色が見える実験(1)では椅子座面の加速度で知覚閵を評価しているが, その他にも床面の振動や椅子の背もたれの応答など，それ以外の要 因が影響している可能性がある。

筆者らが実施した縦じまを視対象とした実験の結果) と比べると, 本実験における視覚の影響は小さい。視覚のみによる知覚を検討し た文献 ${ }^{9)}$ でも述べられているように, 並進振動の場合, 近景と遠景 では知覚に及ぼす影響が異なり，近景を見る場合の方がより敏感に なる。本実験のようにある程度離れた位置にある建物を見る場合之 比べて，空のすぐ外にある緹じまを見る場合には振動の変位を明確 に確認できるため, 視覚の影響がより強く表れているものと考えら れる。本実験では変位が $1.0 \mathrm{~cm}$ 程度より大きい範囲で視覚の影響が 強く現れる傾向にあるが, この境目となる変位の大きさは視覚条件 によって異なることが推察できる。

\section{5. 既往研究における体感知営䦚との比較}

これまでに行った実験(2)〜67 (10.11)における空外の景色が見えな い場合の知覚闒と比較して，視覚が知覚閥に及ぼす影響を位置づけ たのが图11である。空外の景色が見えない場合の知覚闘は，体感に よる知覚閥のばらつきを示す曲線 ${ }^{12)}$ として，実験(2)〜(6)の条件を整 理した上で, データを近似した 3 次曲線で表している。

\begin{tabular}{|c|c|c|c|c|}
\hline 線種 & 実験名 & 評価対象 & 予告 & 被験者状況 \\
\hline \multicolumn{5}{|c|}{ 空外の景色が見える場合 } \\
\hline & 実験(1) & 摇れを感じた合図 & 有り & アンケートに集中 \\
\hline \multicolumn{5}{|c|}{ 空外の景色が見えない場合 } \\
\hline - . - & 实験(2) (5) & 摇れを感じた合図 & 有り & アンケートに集中 \\
\hline$\cdot \cdot \cdot \cdot \cdot \cdots$ & 実験(3) $)^{71}(4)^{107}$ & 「まったく感じない」 & 有り & アンケートに集中 \\
\hline$\ldots \ldots \ldots$ & 実験(6)" & 摇れを感じた合図 & 無し & リラックス \\
\hline
\end{tabular}

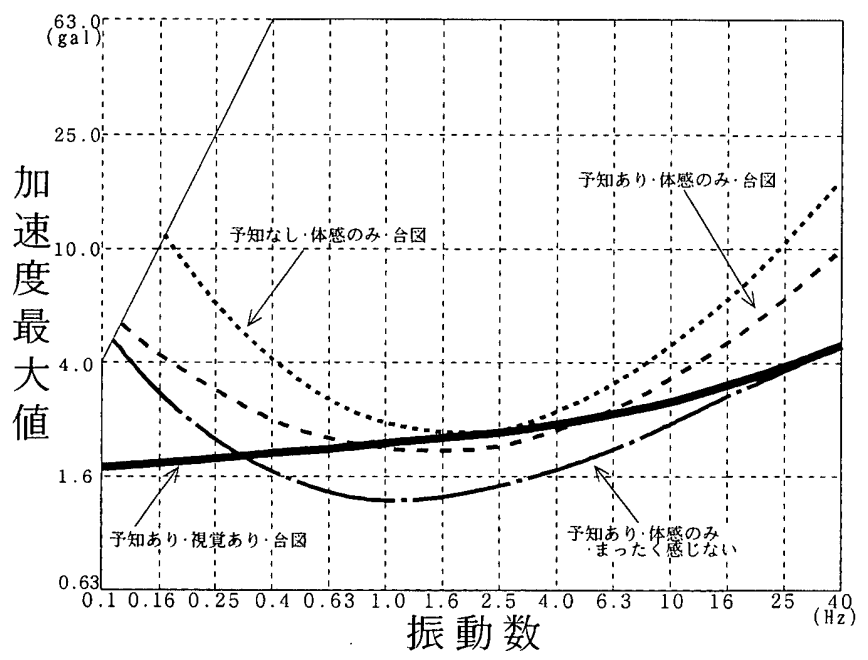

图11 既往研究における体感知觉闑との比較

文献 ${ }^{22}$ で述べたように，体感による知覚闘には被験者の状況や意 識の違いによって図に示すような幅でばらつきが生じる。被験者が 振動の発生を予知せずリラックスした状態で過ごしている場合には 知覚閵は高くなる。一方被験者が振動の発生に対して構えている上, アンケートの指示を受けることで「摇れているのではないか」とい う意識を強くもつ場合には知覚闑が低くなる。日常的な生活環境で 居住者のおかれる状況はどれにもあてはまる可能性があり，知覚闒 におけるこのようなばらつきを考慮した評価が必要になる。

空外の景色が見える場合の知覚閥は， $0.25 \mathrm{~Hz}$ 程度より低振動数範 囲でこれら体感による知覚闑を下回る。すなわち被験者の状況や意 識が体感による知覚闑に及ぼす影響は大きいが，視覚による影響で それを上回る範囲があることがわかる。低振動数範囲では加速度が 小さくても変位が大きいため, 体感では感じない振動も変位を視覚 から認識することで振動を感じるきっかけとなり知覚閥が低くなる。 この範囲では視覚が知覚閥に及ぼす影響は顕著であり，その影響を 考慮した評価が必要になる。

一方 $0.4 \mathrm{~Hz}$ 以上の高振動数範囲では, 変位が小さいことと関連し て視覚が知賞間に及ぼす影響は小さく，主に体感により評価される。 空外の景色が見える場合の知覚閥は体感による知覚闘のばらつきの 範囲内に位置する。この範囲では，視覚の影響を考慮した上でも， 体感による知覚闘のばらつきを主とした評価が可能である。

このように，居住性能評価において対象となる加速度が比較的低 い範囲では，振動数によって視覚が知覚闑に及ぼす影響が異なるた め, 対象建物により体感と視覚に対する重みを変えて評価する必要 がある。例えば 3 階建てプレハブ住宅などの低首建物に生じる 2.0 $\sim 4.0 \mathrm{~Hz}$ 程度の振動範囲 ${ }^{13)}$ は体感による感覚が敏感な範囲であり， それ以外の振動数範囲と比較して視覚の影響は小さい。このような 範囲では，体感を重視した評価が適切である。また超高層住宅など 
に生じる低振動数範囲では，体感では振動を感じにくい一方，視覚 が水平振動感賞に影響を及ぼす可能性が高い。このような範囲では, 評価における視覚の重みを大きくすることが必要になる。

\section{6. おわりに}

視覚が水平振動感覚に及ぼす影響を知るため, 空外の景色が見え るようにして被験者実験を行い，体感のみによる実験結果と比較検 討した。本論文で得られた知見を以下に纏める。

1）視党が水平振動に対する心理評価に及ぼす影響は，振動数範围 によって変化する。加速度が小さくても変位が大きい低振動数 範囲では，視覚の影響により評価が笽しくなる。一方振動数が 高い範囲では体感による感覚と比較して視賞として見える変位 が小さいため，体感のみによる評価の方が放しい傾向にある。 また空外の景色が見える場合, 視覚による感覚と体感による感 覚における違和感が不快感や不安感を助長する一因になること がある。

2) 視覚は知覚闘に大きな影響を及ぼすが，その影響は低振動数範 囲ほど大きい。低振動数範囲では加速度が小さくても変位が大 きいため, 体感で振動を感じなくても視覚から確認できる変位 がきっかけとなり，知覚閜が低くなる。一方振動数が高くなる ほど変位が小さくなるため，高振動数範囲では視覚の影響はほ とんどなく，体感に依存して振動を評価するようになる。

3 ）視覚が水平振動感覚に及ぼす影響は，視覚から認識できる振動 の情報である変位とのかかわりが強く, 変位の大きさによって 3つの範囲に分けて考えることができる。個々の条件によって 視覚から認識できる変位の境目となる大きさは異なるが, これ より変位が小さい場合には，窓外の景色が見えても視賞によっ て振動が認識されないため, 体感のみで評価される。これより 変位が大きい振動に対しては，体感と視賞が相互に影響しあっ て評価され，そのなかでも変位が大きい振動では，視覚の影響 によって評価がより篻しくなる範囲がある。

4）体感による知覚閏は被験者の状況や意識などによってばらつき が生じるが，低振動数範囲では視覚による影遙がそれを上回り， 知党閥はより低くなる。一方，振動数が高い範囲では視党によ る影辢は小さく，視党を考虑した上でも体感による知覚閂のば らつきで主として評価することができる。

本研究により得られた視賞が影䪰する振動範囲は一定の視覚条件 における特性であり，一般化した評価については今後の研究に期待 したい。そのなかで本研究は, 水平振動に対する居住性能を評価す る上で，視賞の影響を考慮すべき範囲と体感に基づいて評価できる 範囲を分けて考える必要があることを明らかにした。
実際の生活環境では居住者の付近に窓があるか, 摇れる物がある か否か, また居住者がそれを見るかなどの可能性が評価にかかわる ことが想定できる。今後は，このような視覚の影響を含め, 個人差 や状況による違いなども考慮した知覚闒のばらつきを確率的に評価 する方法を提示したい。

実験の実施，デー夕解析にあたっては, 当時の当研究室卒論生, 上原翠沙，北川陽子，田宮麗子，渡透みゆ子君にご協力戴いた。こ こに記して感謝の意を表する。また実験にご参加戴いた多くの方々 に深謝する次第である。本研究の一部は文部省科学研究費補助金・ 基盤研究（C）によっている。

\section{引用文献}

1) 日本建築学会 : 建築物の振動に関する居住性能評価指針・同解説, 第 1 版，1991年4月。

2) 石川考重，植草友枝，一力ゆう，野田千律子：高層住宅の居住性をふま えた摇れ感觉に関する調查研究ーその 1 アンケートの概要とその結果 一, 日本建築学会大会学術講演梗概集（祭境工学），pp. 95 96，1993年 9月.

3) 中村敏治, 神田順, 境谷清人, 長屋雅文: 免震建物における地震時振動知喾 の統計的謂查，日本建筑学会榙造系論文集，第472号，pp. 185～192, 1995 年6月.

4) ISO/CD2631-2 : 1997 Mechanical vibration and shock - Evaluation of human exposure to whole-body vibration Part2: Vibration in buildings (1 to $80 \mathrm{~Hz}$ ).

5) 石川孝重，野田千津子，煺澤文俊，盛田恒男：視觉刺激を考虑した強風 時の使用限界に関する 一考察，樹造工学論文集，V0I. 40B，pp. 1 6, 1994 牦3月。

6)石川孝重，野田千津子，限澤文俊，岡田恒男：視対象の違いが水平振動 感覚におよほす影䈏に関する一考察，第13回風工学シンポジウム論文集， pp. 107〜112，1994年.

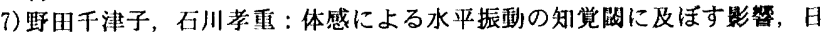

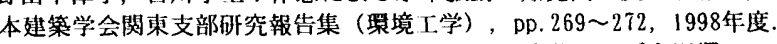

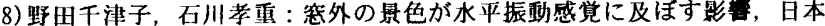
建勧学会関東支部矿究報告集（孟境工学），pp. 273〜276，1998年度.

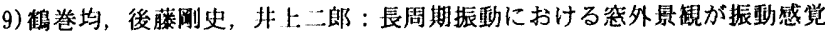
に叉ぼす影替に関する研究ーその 2 振動視覚シュミレー夕実弱の概要

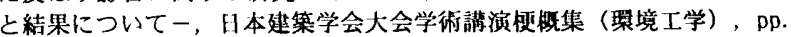
$361 \sim 362 ， 1995$ 年8月.

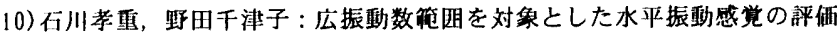
に対する㭘討，日本建筮学会計画系諭文集，第506号，pp.9～16，1998年 4月.

11)石川孝重，野田千泮子他：生活照境に近い状況下での水平振動感覚とそ の評価一その 1 実駼方法の概要と心理評価の特性一; 一その 2 生活

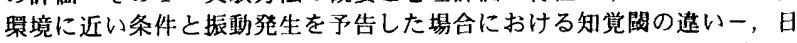

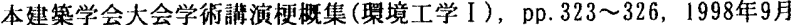

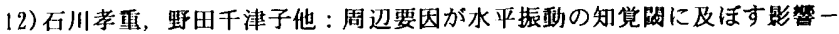

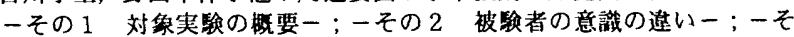
の 3 詊洒曲線の提示一，日本建築学会大会学術詶演梗概集（畹境工学 I)，1999年9月。

13）大築民夫, 田村幸雄，中田信治，内藤俊一，桐山伸…道路交近振動に 起因する鉄骨造住宅の振動性状，日本建築学会大会学術講演梗概集（舆 境工学)，pp. 1885～1886，1994年9月。

（1999年 2 月 8 日原稿受理，1999年 6 月25日採用決定） 